\title{
Indications of the Potential of Shale Gas for Non-Conventional Energy Sources in Indonesia
}

\author{
Fandika Agustiyar a,1,*, \\ ${ }^{a}$ Faculty of Mineral Technology, UPN Veteran Yogyakarta, Jl. SWK 104 Condong Catur, Depok, Sleman, Yogyakarta \\ ${ }^{1}$ fandikaagustiyar@gmail.com* \\ * corresponding author
}

\section{ARTICLE INFO}

\section{Article history}

Received

Revised

Accepted

Keywords

Geochemistry

Shale Gas

TOC

\section{ABSTRACT}

Shale Gas is a potential non-conventional energy source to be developed. However currently, shale gas has not been developed optimally in Indonesia. Therefore, the authors aim to help develop the potential of shale gas by indicating the potential for distribution in Indonesia. The research study was conducted by reviewing literature sourced from literature such as journals, articles, and books. Based on the research conducted, potential shale gas reserves are found in the North Sumatra Basin, Central Sumatra Basin, and South Sumatra Basin. A geochemical method that includes parameters of Total Organic Carbon (TOC), type of kerogen, and maturity level (Ro) is used to develop shale gas potential in an area. Shale gas can be a substitute for conventional fossil fuels, so further studies are needed so that it can be produced commercially.

This is an open-access article under the CC-BY-SA license.

\section{Introduction}

Currently, the fulfillment of energy in Indonesia is still sourced from non-renewable energy sources. Fuel oil and coal play an important and dominant role in the fulfillment of national energy. Primary energy production, which includes hydrocarbons, natural gas, coal, and renewable energy in 2018, reached 411.6 MTOE. It is undeniable that the condition of conventional fuel production in Indonesia has decreased. Based on data [1], hydrocarbon production in the period 2009 to 2018 has decreased; a production that previously reached 346 million barrels in 2009 decreased to 283 million barrels in 2018. Currently, in order to meet the needs of refineries, imports of hydrocarbons from the East it is being carried out and have implications for import dependence with a percentage of $35 \%$. Therefore, efforts are needed to find new energy sources in order to continue to substitute fuel oil; one of these energy sources is shale gas.

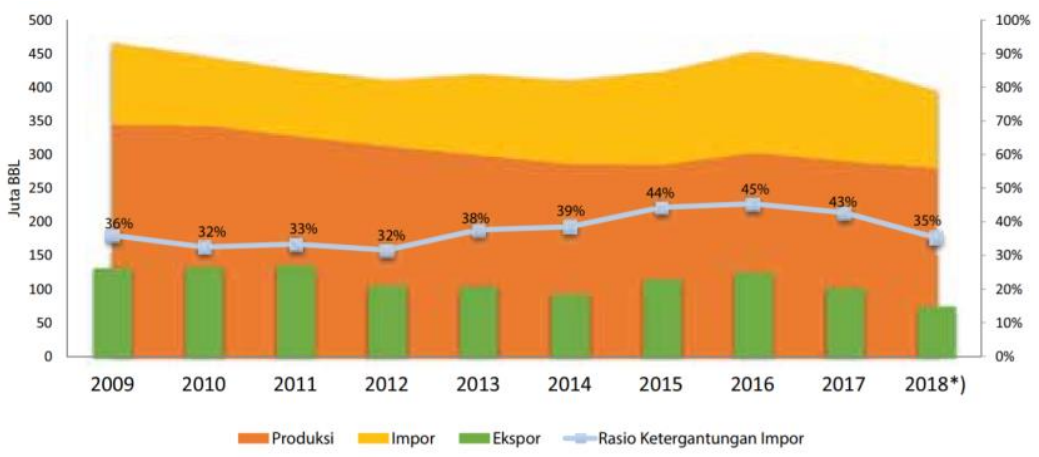

Fig. 1 Graph of production and dependency ratio of oil imports [1] 
Indonesia, as a country rich in energy resources, needs to be explored and utilized optimally; one of Indonesia's natural resources is shale gas. The potential for shale gas in Indonesia is quite large, reaching 574 TCF which is spread across various parts of Indonesia. The Sumatra area is the area with the largest shale gas potential where the condition of the buyer's need for gas is quite high [3]. Compared to conventional gas in Indonesia, the potential for shale gas is indeed greater [4]. Most of the basins are in Sumatra, including the Gumai Shale, Baong Shale, and Telisa Shale. While other places, such as Kalimantan and Java, are in two basins. As for those in Papua, they are in the form of reserve-clasafet.

Shale gas is a natural gas formed from shale rock. Shale is a sedimentary rock that has a grain size component of clay and silt with planar laminate characteristics [5]. The gas that is formed and stored in situ in shale gas is absorbed by organic material, and gas is trapped in the fractured pores. In shale rock, the permeability is very low $(10 \mathrm{MD})$. If it is to produce gas in commercial quantities, it requires quite an intensive fracturing. The shale gas system is part of the petroleum system with conventional and unconventional gas accumulation conditions. Conventional reservoirs are known for their high porosity (10\%) and high permeability (>100 MD), while nonconventional reservoirs have low porosity conditions [4].

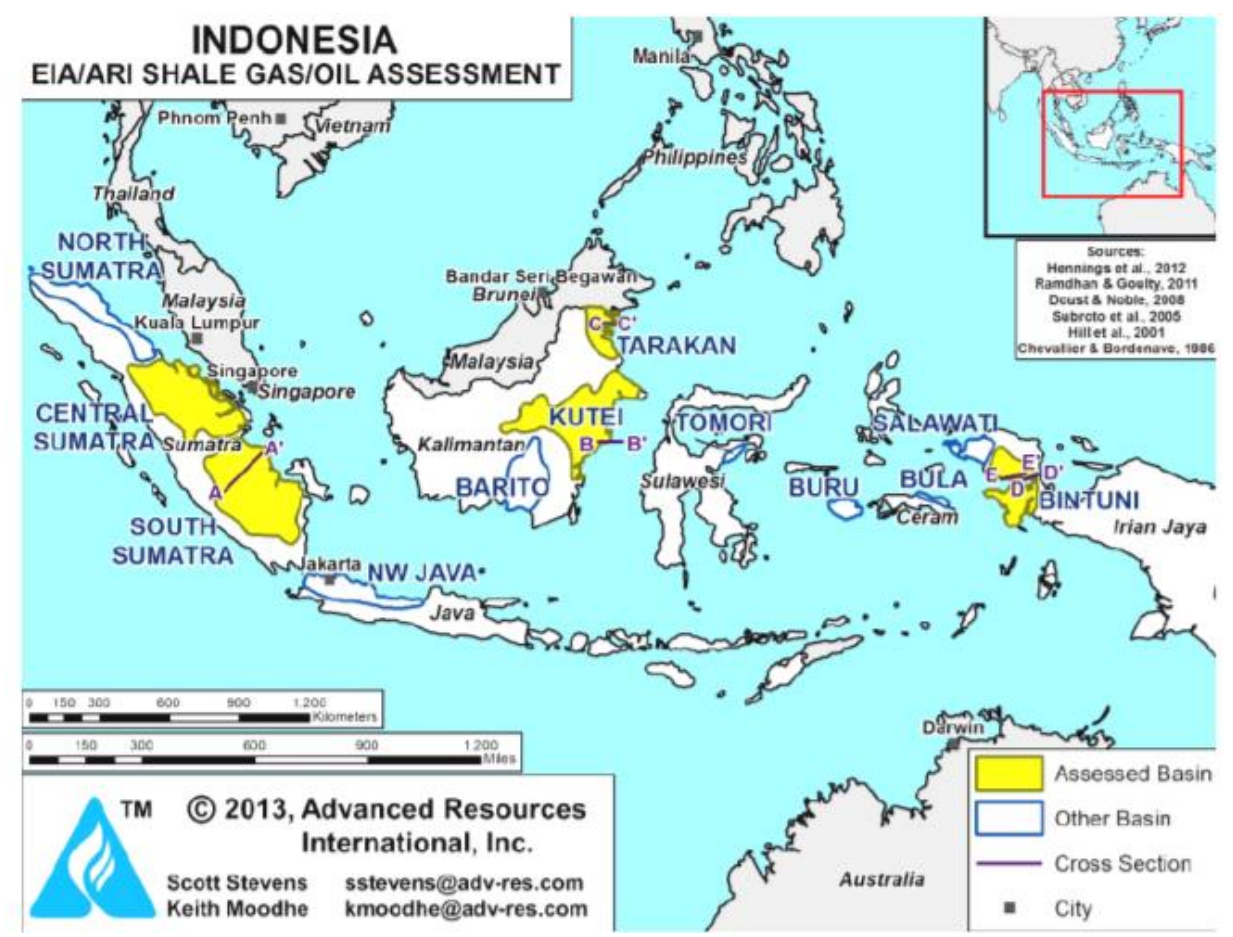

Fig.2 Map of shale gas distribution in Indonesia [6]

Seeing the potential that exists in shale gas as a potential energy source in the future with various advantages and abundance, technology for the production of shale gas on a commercial scale is not yet feasible. Therefore, studies on shale gas through the fields of geology and geophysics must be carried out so that the utilization of energy resources in Indonesia is more optimal. In the exploration stage of shale gas, in general, the exploration concept is similar to conventional gas, but for some parameters, especially in the geochemical aspect, there are differences. Based on this background, the idea emerged to conduct research related to the potential of shale gas resources in order to replace conventional resources in the future. The purpose of this research related to the potential of shale gas is to identify the presence of shale gas in Indonesia by using a geochemical method approach and also paying attention to the geological conditions of the area. 


\section{Method}

This research was conducted with a focus on several regional studies, namely the Sumatra Basin, Central Sumatra Basin, and South Basin. This research approach is carried out by conducting logical reasoning by induction and deduction, namely by conducting a literature review from scientific journals, articles, books, and research that has been done previously regarding research data on shale gas indications in Indonesia, so that it can be used as a basis and reference in the implementation of this research. Literature study is an important thing and needs to be done so that information disclosure can be more comprehensive.

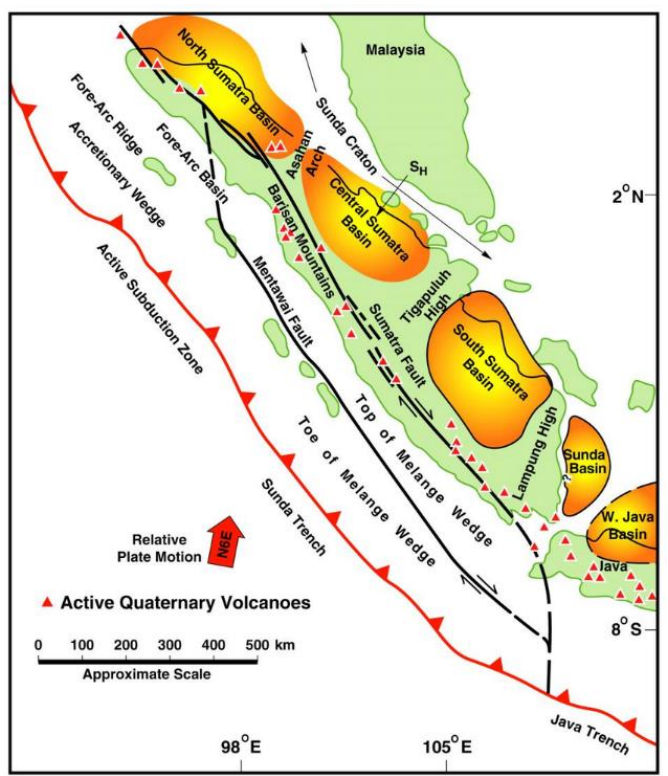

Fig. 3 Sumatra Basin Map [7]

In this study, the data source used is articles, journals, and books that have been published previously in national and international journals, so that the credibility and accuracy of the data used are more assured for this research. Data analysis is conducted by referring to the results and discussion of several related studies conducted earlier so that data on shale gas potential through geological and geochemical aspects are obtained.

The data used to support research on the potential presence of shale gas in the Sumatra Basin include geochemical analysis and basin analysis. Basin analysis data were used, such as data from basin stratigraphic analysis. Geochemical data were used to validate and look for correlations with basin configuration results. The results of geochemical data include total organic carbon (TOC) data, kerogen type, and Ro maturity level. Classification of TOC values is done by referring to Table 1, for classifying kerogen types based on Table 2 classification, maturity level values are classified based on Table 3, and for material analysis and kerogen, characteristics refer to table 4 and table 5 .

Table 1. Geochemical parameters Describing the Petroleum Potential (Quantity) of an Immature Source $\operatorname{Rock}[8]$

\begin{tabular}{ccccccc}
\hline \multicolumn{7}{c}{ Organic Matter } \\
\hline $\begin{array}{c}\text { Petroleum } \\
\text { Potential }\end{array}$ & TOC & \multicolumn{2}{c}{ Rock-Eval Pyrolysis } & \multicolumn{2}{c}{ Bitumen } & Hydrocarbons \\
\cline { 2 - 7 } & $(\mathrm{wt} \%)$ & $\mathrm{S}_{1}{ }^{\mathrm{a}}$ & $\mathrm{S}_{2}{ }^{\mathrm{b}}$ & $(\mathrm{wt} \%)$ & $(\mathrm{ppm})$ & $(\mathrm{ppm}$ \\
\hline Poor & $0-0.5$ & $0-0.5$ & $0-2.5$ & $0-0.05$ & $0-500$ & $0-300$ \\
\hline Fair & $0.5-1$ & $0.5-1$ & $2.5-5$ & $0.05-0.10$ & $500-1000$ & $300-600$ \\
\hline Good & $1-2$ & $1-2$ & $5-10$ & $010-0.20$ & $1000-2000$ & $600-1200$ \\
\hline Very Good & $2-4$ & $2-4$ & $10-20$ & $0.20-0.40$ & $2000-4000$ & $1200-2400$ \\
\hline Excellent & $>4$ & $>4$ & $>20$ & $>0.40$ & $>4000$ & $>2400$ \\
\hline
\end{tabular}

${ }^{\mathrm{a}} \mathrm{mg} \mathrm{HC/g}$ dry rock distilled by pyrolysis.

${ }^{\mathrm{b}} \mathrm{mg} \mathrm{HC} / \mathrm{g}$ dry rock cracked from kerogen by pyrolysis.

Evaporation of the solvent used to extract bitumen from a source oil from a reservoir rock causes loss of the volatile hydrocarbons below about $n$ - $\mathrm{C}_{15}$. Thus, most extracts are described as $\mathrm{C}_{15+}$ hydrocarbons. ${ }^{*}$ Lighter hydrocarbons can be at least partially retained by avoiding complete evaporation of the solvent (e.g., $\left.\mathrm{C}_{10+}\right)$ 
Table 2. Geochemical Parameters Describing Kerogen Type (Quality) and the Character of Expelled Products[8]

\begin{tabular}{ccccc}
\hline & HI & & & $\begin{array}{c}\text { Main Expelled } \\
\text { Product at Peak } \\
\text { Maturity }\end{array}$ \\
\hline Kerogen Type & $(\boldsymbol{m} \boldsymbol{H} \boldsymbol{H C} / \boldsymbol{g}$ TOC $)$ & $\boldsymbol{S}_{2} / \boldsymbol{S}_{\mathbf{3}}$ & Atomic H/C & Oil \\
\hline I & $>600$ & $>15$ & $>1.5$ & Oil \\
\hline II & $300-600$ & $10-15$ & $1.2-1.5$ & Mixed oil and gas \\
\hline II/III ${ }^{\mathrm{b}}$ & $200-300$ & $5-10$ & $1.0-1.2$ & None \\
\hline III & $50-200$ & $1-5$ & $0.7-1.0$ & $<0.7$ \\
\hline IV & $<50$ & $<1$ &
\end{tabular}

${ }^{\mathrm{a}}$ Based on a thermally immature source rock. Ranges are approximate.

type II/III designates kerogens with compositions between type II and III pathways that show intermediate HI

Table 3. Geochemical parameters describing the level of thermal maturation[8]

\begin{tabular}{lcc}
\hline \multicolumn{1}{c}{$\begin{array}{c}\text { Stage of Thermal } \\
\text { Maturity }\end{array}$} & $\mathbf{R}_{\mathbf{0}}$ & $\mathbf{T}_{\max }$ \\
\cline { 2 - 3 } & $\mathbf{( \% )}$ & $\left({ }^{\circ} \mathbf{C}\right)$ \\
\hline Immature & $0.2-0.6$ & $<435$ \\
\hline Mature & & \\
\hline Early & $0.6-0.65$ & $435-445$ \\
\hline Peak & $0.65-0.9$ & $445-450$ \\
\hline Late & $0.9-1.35$ & $450-470$ \\
\hline Postmature & $>1.35$ & $>470$ \\
\hline
\end{tabular}

Table 4. Kerogen type character[9]

\begin{tabular}{cccc}
\hline Kerogen Type & Type I & Type II & Type III \\
\cline { 2 - 4 } Kerogen Source : & $\begin{array}{c}\text { Marine algae and } \\
\text { plankton }\end{array}$ & $\begin{array}{c}\text { Marine and terrestrial } \\
\text { plant and animal } \\
\text { material }\end{array}$ & $\begin{array}{c}\text { Terrestial plant } \\
\text { material }\end{array}$ \\
\hline $\begin{array}{c}\text { Hydrogen to Carbon } \\
\text { ratio }\end{array}$ & $>1.25$ & $<1.25$ & $<1.0$ \\
\hline Oxygen to carbon ratio & $<0.15$ & $0.03-0.18$ & $0.03-0.3$ \\
\hline $\begin{array}{c}\text { Hydrocarbon } \\
\text { formation propensity }\end{array}$ & $\begin{array}{c}\text { Rich in hydrogen and } \\
\text { poor in oxygen and } \\
\text { thus tend to produce } \\
\text { liquid oil }\end{array}$ & $\begin{array}{c}\text { Produce liquid oil } \\
\text { and/or gas. }\end{array}$ & $\begin{array}{c}\text { Low in hydrogen and } \\
\text { high in carbon, so it } \\
\text { produces mainly coal. }\end{array}$ \\
\hline
\end{tabular}

Table 5. The four types of kerogen, the macerals that they are composed of, and their organic precursors[10].

\begin{tabular}{ccc}
\hline Maceral & Kerogen Type & Original OM \\
\hline Alginite & I & Freshwater algae \\
\hline Excite & II & Pollen, spores \\
\hline Cultivate & II & Land-plant cuticle \\
\hline Resinite & II & Land-plant resins \\
\hline Liptinite & II & All land-plant lipids; marine algae \\
\hline Vitrinite & III & Woody and cellulosic material from land plants \\
\hline Inertinite & IV & Charcoal; highly oxidized or reworked material of any origin \\
\hline
\end{tabular}




\section{Results and Discussion}

\subsection{Shale Gas Formation}

Shale gas is seen structurally geologically in ideal conditions in the cyclone zone (figure 4). According to [11], in the formation of shale gas in shale rocks, there are several conditions: a) has a content of TOC $>1 \%$, with black flakes facies, b) generally in the form of kerogen type III, c) immature maturity level, d) the obtainability of clay minerals, e) depth is not too deep.

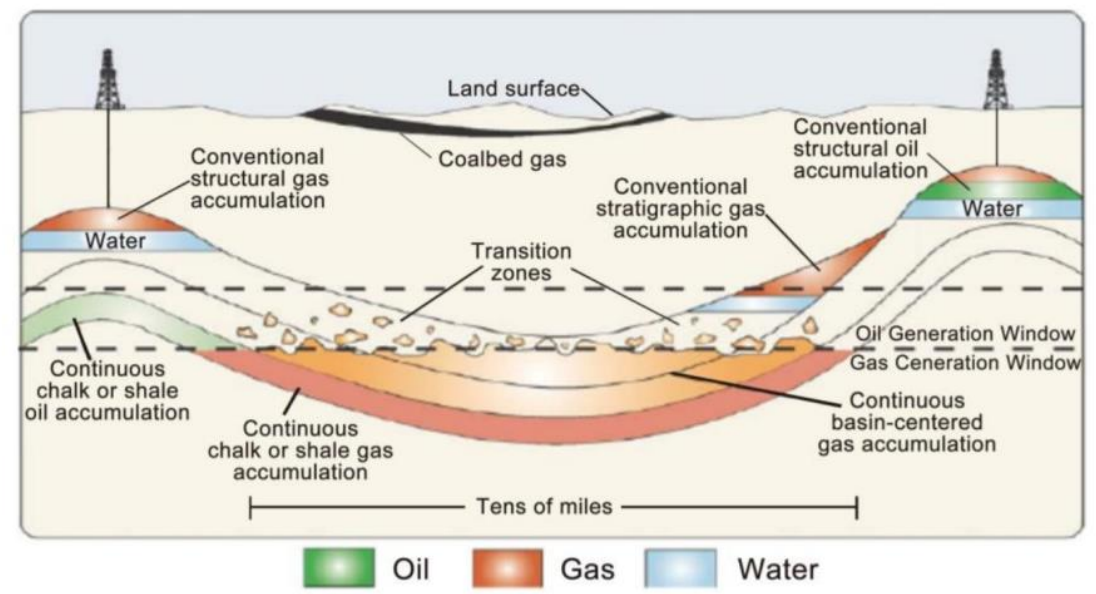

Fig. 4 Generalized diagram showing categories of conventional and continuous oil and gas accumulations [12]

This gas is produced and stored insitu in shale gas as adsorbed gas that is gas absorbed in organic material and free gas that is gas stuck in the crack or pore. Very low shale rock permeability $(<10 \mathrm{mD})$ requires intensive drilling to produce gases that quantity meet commercial aspects. A shale gas system is part of a petroleum system with accumulated gases of a conventional or non-conventional nature [5]. Conventional reservoirs are rocks with high porosity conditions $(>10 \%)$ and high permeability $(>100 \mathrm{mD})$, while non-conventional reservoirs are rocks with small porosity conditions.

\subsection{Shale Gas Potential in Indonesia}

According to official data [13] based on the Indonesian Geological Agency, the potential of shale gas resources spread across 14 basins in Sumatra, Java, Kalimantan, Sulawesi, and Papua amounts to 16.3 trillion cubic meters (574 trillion cubic feet) of gas in place, as seen in Table 6.

Table 6. Indonesian shale gas resources by region and basin[13]

\begin{tabular}{cccc}
\hline \multirow{2}{*}{ Region } & \multirow{2}{*}{ Basin/Formation } & Total gas in place & Total gas in place \\
\cline { 2 - 4 } & & $\mathbf{( T c m})$ & $(\boldsymbol{T c f})$ \\
\hline \multirow{5}{*}{ Sumatra } & 1.8 & 64.8 \\
\cline { 2 - 4 } & North Sumatra & 2.5 & 86.9 \\
\cline { 2 - 4 } & Central Sumatra & 0.7 & 25.3 \\
\cline { 2 - 4 } & Ombilin & 1.6 & 56.1 \\
\cline { 2 - 4 } Java & South Sumatra & 6.6 & 233.1 \\
\cline { 2 - 4 } & Subtotal & 0.2 & 5.6 \\
\cline { 2 - 4 } & Northwest Java & 1.2 & 42.0 \\
\cline { 2 - 4 } & Northeast Java & 1.4 & 47.6 \\
\hline \multirow{3}{*}{ Kalimantan } & Subtotal & 2.1 & 74.6 \\
\cline { 2 - 4 } & Barito & 2.3 & 80.6 \\
\cline { 2 - 4 } & Kutei & 0.2 & 11.9 \\
\cline { 2 - 4 } & Tarakan & 0.3 & 19.6 \\
\cline { 2 - 4 } & Melawai & 0.6 & \\
\cline { 2 - 4 } & Ketungau & & \\
\hline
\end{tabular}




\begin{tabular}{cccc}
\hline & Subtotal & 5.5 & 193.9 \\
\hline \multirow{3}{*}{ Sulawesi } & Sengkang & 0.2 & 5.4 \\
\hline \multirow{3}{*}{ Papua } & Akimeugah & 1.8 & 62.4 \\
\cline { 2 - 4 } & Bintuni & 0.9 & 31.4 \\
\cline { 2 - 4 } & Subtotal & 2.7 & 94.0 \\
\hline & Total & 16.3 & 574.1 \\
\hline
\end{tabular}

In assessing the potential of shale gas, there are aspects that affect, including the following:

1. Deposition Environment

The environment of the deposition process that occurs becomes important in determining the potential of shale gas, whether the gas is deposited in the marine or non-marine environment. The characteristics of flakes deposited in the sea have the characteristics of a small content of clay, and existing minerals tend to be more brittle such as carbonate, feldspar, and quartz. In contrast to flakes deposited in a land or lake environment, usually, the content of clay minerals is more and tends to be ductile so that less good response occurs when simulated hydraulic fracturing.

\section{Depth}

In shale gas disciplining, the ideal depth ranges from more than $1000 \mathrm{~m}-5000 \mathrm{~m}$. Depth conditions less than $1000 \mathrm{~m}$ are usually low pressure, and gas concentration is also low. The condition of shale gas formation at shallow depths will have an impact on the level of water content that is quite high due to contact with fractures in the area.

\section{Total organic Carbon (TOC)}

Organic carbon content in areas where shale gas prospects $\geq 2 \%$ value. The formation of gas components required, such as organic materials, plays a role in producing carbon, oxygen, and hydrogen.

\section{Maturity}

In areas that have the prospect of shale gas, ideally, Ro>1 value, if the ro value is higher, then the porosity of the rock will be as large.

\section{Geography Location}

Areas with basins in the process of shale gas formation.

\subsection{Indications of shale gas potential}

\section{North Sumatra Basin}

Based on data that has been processed by [14] sourced from PT Pertamina Hulu Energi Sumbangut. The data is geochemical data that includes the amount of organic material (\%TOC), kerogen type, and maturity level (\% Ro).

Table 7. Geochemical Data of Bampo, Baong Bawah, and Belumai Formations [14]

\begin{tabular}{cccc}
\hline Formation & Bampo & Baong Bawah & Belumai \\
\hline TOC (\%) & $0.6-1.1$ & $1.15-1.47$ & $0.46-1.18$ \\
\hline Type Kerogen & III & II \& III & III \\
\hline \% Ro & $1.19-1.36$ & $0.2-0.9$ & $0.2-0.9$ \\
\hline
\end{tabular}

The Sumatra Basin has potential formations for organic materials. Geochemical data stabilization includes the formations of Bampo, Bawong Bawah, and Belumai. The Bampo formation is a formation that is precipitated in the position of the Parapat Formation. Lithology in Bampo formation is dominated by clay material with dark gray blackish color, mudstone, and lanai and found nodules - carbonate nodules [15]. Bampo formation deposition environment is in a restricted basin area with type III kerogen deposition, based on classification [10] participated 
in maceral vitrinite category. Toc value obtained in the range of $0.6-1.1 \%$, the value is included in the classification of fair good refers to the classification of TOC [8].

Baong formation has a lithology in the form of claystone with the appearance of greenishgray Abi and napal that contains tufa material. The middle part of the rock-earned formation. Napal components and mudstones undergo precipitation in the inner-outer and upper neritic. In the formation of Bawong, Bawah obtained a varied TOC value with an average - rat value of $1.15-1.47 \%$, based on the classification of TOC included in the classification of good. There are two types of kerogen in the Bawong Bawah formation, namely kerogen II and III. Type two kerogen deposition in the Bawong Bawah formation is in the deep ocean basin environment, and for type III kerogen is indicated to be organic land material that undergoes transport process during the formation of the Bawong Bawah formation. The maturity level value in the Bawong Bawah formation of $0.2-0.9 \%$ is included in the Immature classification; the classification is based on [8].

The Belumai formation in prose deposition occurs in harmony above the Bampo Formation. In this formation there are components in the form of Batugamping hasga and Batupasir Belumai (Agrarianda \&Djohor, 2020). The main lithology is sandstone with the appearance of darkgreenish gray, in weathered conditions yellow; contained glauconitic and limestone materials. The Formation of Belumai is known to have a TOC value of $0.46-1.18 \%$, based on the value is included in the good fair classification equal to bampo formation. The formation of Belumnai has a type of kerogen III, where the deposition environment occurs on the shelf. The maturity level of the Belumnai formation is $0.3-0.8 \%$, in this formation indicates the type of oil window maturity.

\section{Central Sumatra Basin}

In the Sumatra Basin, a review of shale gas indications was conducted on the Telisa formation and the Telisa formation, and the formation evaluation was conducted by plotting a zone that has the potential as a shale gas reservoir. Based on the geochemical analysis conducted [16], obtained total organic carbon content (TOC) of $2.01-4.74 \%$ based on classification [8] is included in the excellent classification. The maturity value obtained in the Opposing Formation is $0.63-0.69 \%$; this value is included in the early-peak kerogen type in the opposing formation dominated by types II and III [17].

The Telisa formation is a formation with shale and laminated shale constituent components deposited in the Early - Middle Miocene period. The vertical thickness of the Telisa formation is quite varied in the area ranging from 400-870 feet. In the formation of Telisa based on the analysis of geochemical data by [9] obtained total organic carbon (TOC) value is between $3.13 \%$ - $14.8 \%$, based on classification [8] belongs to the excellent class, the deposition that occurs dominated by alginite and liptinite so that it is selfish as kerogen type II.

After the text edit has been completed, the paper is ready for the template. Duplicate the template file by using the Save As command, and use the naming convention prescribed by your conference for the name of your paper. In this newly created file, highlight all of the contents and import your prepared text file. You are now ready to style your paper; use the scroll-down window on the left of the MS Word Formatting toolbar.

\section{South Sumatra Basin}

Talangakar formation is a formation dominated by material components in the form of shells and clay stones [18]. Talangakar formation undergoes irregular precipitation on top of lahat formation; this formation is divided into two parts, namely GRM (grit sand member), which includes rough clastic with shale inserts and TRM (transitional member) contained in shale. The deposition environment is in the litoral environment until swallow marine with the lifespan of the final oligos - the early Miocene. The thickness of this formation is quite varied, which ranges from $100-500 \mathrm{~m}$.

The results of the analysis conducted on talangakar formation obtained a total organic content value (TOC) of $0.4-0.8 \%$. The type of kerogen in Talangakar formation is quite varied but dominated by type II/III in type III hydrogen content value of $50-400 \mathrm{mg} \mathrm{HC} / \mathrm{gTOC}$. The 
maturity level (Ro) value of the parent rock is at $0.5 \%-1.2 \%$ [19]. Based on the value obtained, the maturity level is included in the peak mature classification.

\section{Conclusion}

Indications of the potential presence of shale gas in the Territory of Indonesia can be found at several points in Sumatra. This is evidenced by geochemical measurements conducted in the North Sumatra Basin (Bampo Formation, Lower Bawong, and Belumai), Central Sumatra Basin (Pemantang and Telisa Formation), and South Sumatra Basin (Talangakar Formation), from the results of measurements and analysis known in the North Sumatra Basin, Central Sumatra Basin, and South Sumatra Basin have different characteristics, it is influenced by the environmental deposition system. Based on the identification of three basins, tiles formation has the greatest potential for gaseous formation. TOC content with a value of $3.13 \%-14.80 \%$ is considered very good in supporting the formation of gas, in addition, supported by dominant lithology in the form of alginate and liptinite. Regarding the development of new energy in the future, it is necessary to research deeply to multiply the potential of shale gas resources in Indonesia in order to be an alternative in meeting future energy needs.

\section{References}

[1] DEN, Indonesia Energy Out Look 2019, no. 2527-3000. Jakarta: Dewan Energi Nasional, 2019.

[2] D. H. Lathifah and T. Yunianto, "Hubungan Antara Fungsi Tutupan Vegetasi Dan Tingkat Erosi Das Secang Kabupaten Kulonprogo," J. Bumi Indones., vol. 2, no. 1, pp. 106-114, 2013, [Online]. Available: http://lib.geo.ugm.ac.id/ojs/index.php/jbi/article/view/133.

[3] SKK Migas, "Focus Group Discussion (FGD) Kajian Parameter Cadangan Shale Gas dan Shale Oil," 2019, 2021. https://www.skkmigas.go.id/berita/focus-group-discussion-fgd-kajian-parametercadangan-shale-gas-dan-shale-

oil?_cf_chl_jschl_tk_=9b30227c6bfc1728269cc9265bc87958f6745d4d-1624458052-0-

AQOk4BpHyBiaMXlqcQapkIeHo0AUTD9T1FH0sVvgnVGbwY7ad0-3YczYF1y9GFhIj6gIzk.

[4] Fitria, "Berburu Migas Non Konvesional,” J. Chem. Inf. Model., vol. 53, no. 9, pp. 1689-1699, 2013.

[5] P. E. Potter, J. B. Maynard, and P. Wayne Arthur, Sedimentology of Shale. Cincinnati: SpringerVerlag, 1980.

[6] APERC, "Pathways to Shale Gas Development in Asia-Pacific," Tokyo, 2015.

[7] A. Aswan, Y. Zaim, and Y. Rizal, "Evaluasi Batuan Sumber pada Serpih Coklat, Kelompok Pematang, Cekungan Sumatera Tengah: Detail Analisis Siklus Sedimen Berbasis Taphonomik Moluska Lacustrine Abstrak,” 2009.

[8] K. E. Peters and M. R. Cassa, “Applied source rock geochemistry," Pet. Syst. - from source to trap, no. March, pp. 93-120, 1994.

[9] M. T. Gandapradana, U. Padjadjaran, and K. M. Universitas, "Shale in Telisa Formation, Central Sumatera Basin as a Prospective Shale Gas Resource Based on Geochemical Data Analysis," in Second EAGE/SPE/AAPG Shale Gas Workshop, 2014, no. September 2014.

[10] D. W. Waples, Geochemistry in Petroleum Exploration. 1985.

[11] M. H. H. Zajuli and R. Oktavitania, "Geokimia Organik Serpih Hidrokarbon Berumur Eosen di Daerah Sumatera Bagian Tengah Organic Geochemistry of the Eocene Hidrocarbon Shale in Central Part of Sumatera Area," vol. 21, no. 1, pp. 45-60, 2020.

[12] R. M. Pollastro, R. J. Hill, D. M. Jarvie, and M. E. Henry, "Assessing undiscovered resources of the Barnett-Paleozoic total petroleum system, Bend Arch-Fort Worth Basin Province, Texas," AAPG Southwest Sect. Meet., vol. 10034, p. 18, 2003, [Online]. Available: http://www.searchanddiscovery.com/pdfz/documents/pollastro/images/article.pdf.html. 
[13] R. S. R.Fakhruddin, "Unconventional Oil and Gas Potential in Indonesia with Special Attention to Shale Gas and Coal-bed Methane," Geol. Agency, vol. Presentation, 2013.

[14] L. N. Galih, I. Haryanto, Y. Firmansyah, and Y. T. Wibowo, "Potensi Shale Gas Di Sub-Cekungan Dalaman Tamiang Dan Langkat, Sumatera Utara," Padjadjaran Geosci. J., vol. 3, no. 3, pp. 163 $167,2019$.

[15] Y. Agrarianda and D. S. Djohor, "Karakteristik Serpih Formasi Bampo di Lapangan " JRC ' Berdasarkan Data XRD dan Geokimia Sebagai Sumberdaya Hidrokarbon Serpih " Shale Characteristics of Bampo Formation in The " JRC " Field Based on XRD and Geochemical D ata as Shale Hydrocarbon Resource," vol. 1, no. 1, pp. 1-9, 2020.

[16] A. Haris, M. B. Marbun, A. Bachtiar, and A. Riyanto, "Geochemical analysis of shale gas reservoir based on good log and 3D seismic data in Pematang formation, Central Sumatera Basin," AIP Conf. Proc., vol. 1862, no. 2017, 2017, DOI: 10.1063/1.4991280.

[17] Reza Mohammad Ganjar Gani, Yusi Firmansyah, and Nisa Nurul Ilmi, "Evaluasi Batuan Induk SubCekungan Aman Utara, Cekungan Sumatra Tengah Dengan Parameter Tipe Material Asal, Kekayaan Dan Kematangan," p. 6, 2016, [Online]. Available: https://seminar.ftgeologi.unpad.ac.id/wpcontent/uploads/2016/07/2.36.pdf.

[18] Jamaluddin, M. F. I. Massinai, and E. Syamsuddin, "Karakterisasi Serpih Pada Formasi Talangakar Sebagai Potensi Shale Hydrocarbon," J. Geocelebes, vol. 2, no. 1, p. 31, 2018, doi: 10.20956/geocelebes.v2i1.3563.

[19] A. A. Achmad, "Studi Potensi Shale Gas Cekungan Sumatera Selatan," in Seminar Nasional ke-II FTG Universitas Padjadjaran, 2015, pp. 92-94. 